\title{
De novo synthesis of a sunscreen compound in vertebrates
}

\author{
Andrew R Osborn ${ }^{1 \dagger}$, Khaled H Almabruk ${ }^{1 \dagger}$, Garrett Holzwarth ${ }^{2,3+}$, \\ Shumpei Asamizu ${ }^{1 \neq}$, Jane LaDu ${ }^{4}$, Kelsey M Kean ${ }^{5}$, P Andrew Karplus ${ }^{5}$, \\ Robert L Tanguay ${ }^{4}$, Alan T Bakalinsky ${ }^{2}$, Taifo Mahmud ${ }^{1 *}$
}

${ }^{1}$ Department of Pharmaceutical Sciences, Oregon State University, Corvallis, United States; ${ }^{2}$ Department of Food Science and Technology, Oregon State University, Corvallis, United States; ${ }^{3}$ Department of Microbiology, Oregon State University, Corvallis, United States; ${ }^{4}$ Department of Environmental and Molecular Toxicology, Oregon State University, Corvallis, United States; ${ }^{5}$ Department of Biochemistry and Biophysics, Oregon State University, Corvallis, United States
*For correspondence: taifo. mahmud@oregonstate.edu

TThese authors contributed equally to this work

Present address: ${ }^{\ddagger}$ Department of Biotechnology, Graduate School of Agricultural and Life Sciences, The University of Tokyo, Bunkyo, Japan

Competing interests: The authors declare that no competing interests exist.

Funding: See page 12

Received: 05 December 2014 Accepted: 29 March 2015

Published: 12 May 2015

Reviewing editor: Wilfred A van der Donk, Howard Hughes Medical Institute, University of Illinois at Urbana-Champaign, United States

Copyright Osborn et al. This article is distributed under the terms of the Creative Commons Attribution License, which permits unrestricted use and redistribution provided that the original author and source are credited.
Abstract Ultraviolet-protective compounds, such as mycosporine-like amino acids (MAAs) and related gadusols produced by some bacteria, fungi, algae, and marine invertebrates, are critical for the survival of reef-building corals and other marine organisms exposed to high-solar irradiance. These compounds have also been found in marine fish, where their accumulation is thought to be of dietary or symbiont origin. In this study, we report the unexpected discovery that fish can synthesize gadusol de novo and that the analogous pathways are also present in amphibians, reptiles, and birds. Furthermore, we demonstrate that engineered yeast containing the fish genes can produce and secrete gadusol. The discovery of the gadusol pathway in vertebrates provides a platform for understanding its role in these animals, and the possibility of engineering yeast to efficiently produce a natural sunscreen and antioxidant presents an avenue for its large-scale production for possible use in pharmaceuticals and cosmetics.

DOI: 10.7554/eLife.05919.001

\section{Introduction}

The sunscreen compounds, mycosporine-like amino acids (MAAs) and related gadusols, commonly found in bacteria, fungi, algae, and marine invertebrates (Shick and Dunlap, 2002; Miyamoto et al., 2014), have been proposed to fulfill a variety of functions, such as sunscreen, antioxidant, stress response, intracellular nitrogen reservoir, and/or optical filter (Gao and Garcia-Pichel, 2011; Bok et al., 2014). Although their formation had long been proposed to originate from the shikimate pathway, more recent bioinformatic and biochemical studies revealed that in cyanobacteria, MAAs are synthesized by desmethyl-4-deoxygadusol synthase (DDGS), a dehydroquinate synthase (DHOS) homolog (Wu et al., 2007; Balskus and Walsh, 2010; Singh et al., 2010; Asamizu et al., 2012). Interestingly, inactivation of the DDGS gene in Anabaena variabilis ATCC 29413 did not abolish the production of MAAs, suggesting that additional pathways exist for the biosynthesis of MAAs (Spence et al., 2012). DDGS converts sedoheptulose 7-phosphate (SH7P) to desmethyl-4-deoxygadusol via a unique sequence of dephosphorylation, aldol condensation, enolization, dehydration, reduction, and tautomerization reactions (Figure 1-figure supplement 1) (Balskus and Walsh, 2010; Asamizu et al., 2012). The product is subsequently converted by a methyltransferase to 4-deoxygadusol, the building block of MAAs.

4-Deoxygadusol has also been proposed to be the precursor of gadusol (Starcevic et al., 2010; Rosic and Dove, 2011), a related compound initially isolated from cod roe (Gadus morhua L.) (Plack et al., 1981), but also found in roes of other marine fish (Plack et al., 1981; Arbeloa et al., 2010), 
eLife digest Sunlight is the Earth's primary energy source and is exploited by an array of natural and man-made processes. Photosynthetic plants harness solar energy to convert carbon dioxide and water into biomass, and solar panels capture light and convert it to electricity. Sunlight is critical to life on Earth, and yet excessive exposure to sunlight can cause serious harm as it contains ultraviolet (UV) radiation, which damages the DNA of cells. In humans, this damage can lead to conditions such as cataracts and skin cancer.

The marine organisms and animals that live in the upper ocean and on reefs are subject to intense and unrelenting sunlight. In their effort to protect against potentially deadly UV radiation, many small and particularly vulnerable marine organisms, such as bacteria and algae, produce UV-protective sunscreens. While UV-protective compounds have also been found in larger organisms, including fish and their eggs, the presence of these sunscreens has always been attributed to the animal sequestering the compounds from their environment or partnering with a sunscreen-producing microorganism.

Now, Osborn, Almabruk, Holzwarth et al. have discovered a fish that is able to produce such a UVprotective compound completely on its own. After identifying the full set of genes-or

pathway-responsible for generating the UV-protective compound, the same pathway was detected in a variety of diverse animals, including amphibians, reptiles, and birds. This opens up a new area of study, because besides providing UV protection, no one yet knows what other roles the molecule may have in these animals. Furthermore, introducing the complete pathway into yeast enabled these cells to produce the sunscreen. In the future, engineering a yeast population to produce large quantities of the natural sunscreen could lead to large-scale production of the UV-protective compound so it can be used in pharmaceuticals and cosmetics.

DOI: 10.7554/eLife.05919.002

sea urchin eggs (Chioccara et al., 1986), cysts and nauplii of brine shrimp (Grant et al., 1985), mantis shrimp crystalline cones (Bok et al., 2014), and sponges (Bandaranayake et al., 1997). As genes responsible for the production of 4-deoxygadusol and MAAs are commonly found in bacteria (e.g., cyanobacteria), algae, and other marine microorganisms (Shick and Dunlap, 2002; Miyamoto et al., 2014), the accumulation of these compounds in marine animals has been proposed to be of dietary or symbiont origin (Arbeloa et al., 2010; Gao and Garcia-Pichel, 2011; Loew, 2014). On the other hand, a gene cluster like that in cyanobacteria apparently encoding a four-step DDGS-based pathway for converting SH7P to MAAs was discovered in the genomes of a coral (Acropora digitifera) and sea anemone (Nematostella vectensis), suggesting that these invertebrates can produce MAAs autonomously (Rosic and Dove, 2011; Shinzato et al., 2011).

DDGS is a member of the sugar phosphate cyclase (SPC) superfamily (Wu et al., 2007). In addition to DHQS, this superfamily includes four enzymes known for their roles in the biosynthesis of natural products with therapeutic application: 2-epi-5-epi-valiolone synthase (EEVS), 2-epi-valiolone synthase, aminoDHQS, and 2-deoxy-scyllo-inosose synthase (DOIS) (Wu et al., 2007; Mahmud, 2009; Asamizu et al., 2012; Kang et al., 2012). EEVS catalyzes the entry step to the biosynthesis of pseudosugarcontaining natural products, such as the antidiabetic drug acarbose and the crop protectant validamycin A, and has so far only been identified and characterized in bacteria (Mahmud, 2009).

Recently, we surprisingly also found genes that encode EEVS-like proteins (annotated as 'PREDICTED: pentafunctional AROM polypeptide-like') in the genomes of fish, amphibians, reptiles, and birds (Figure 1A, Figure 1-figure supplement 2, Table 1, Figure 1-source data 1). This gene is located in a cluster with another functionally unknown gene (labeled as MT-Ox hereafter) and flanked by a suite of transcription factor genes encoding FRMD4B, MitF, MDFIC, and FoxP1 (Figure 1B). These transcription factors have been known to regulate the expression of genes with essential roles in cell differentiation, proliferation, and survival (Levy et al., 2006; Rice et al., 2012; Garner et al., 2014; Zhao et al., 2015). However, whether they have a direct functional relationship with the EEVS and MT-Ox genes remains an open question. Whereas humans and other mammals also have FRMD4B, MitF, MDFIC, and FoxP1 homologs, they lack the EEVS-like and the MT-Ox genes (Figure 1B). Therefore, the presence of the EEVS-like gene, previously only found in bacteria, in the genomes of fish, and other egg-laying vertebrates is puzzling and evolutionarily intriguing. Here, we 
A
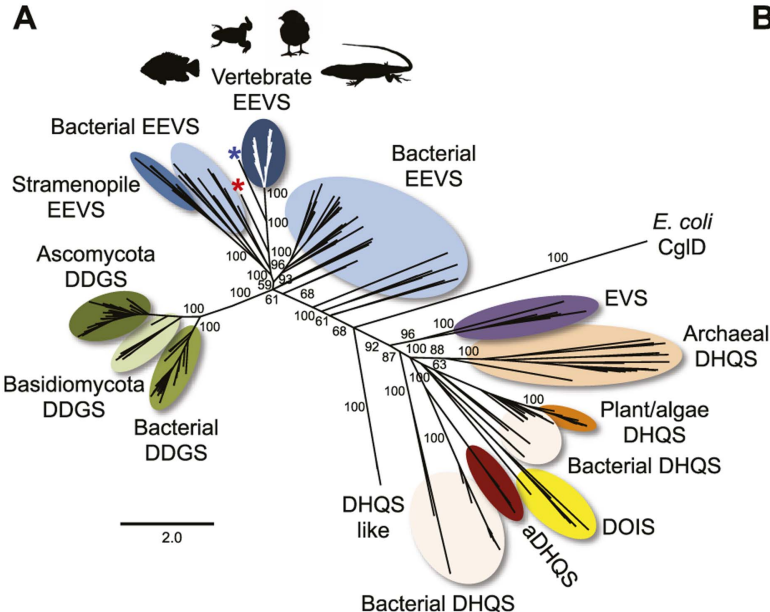

Bacterial DHQS

C

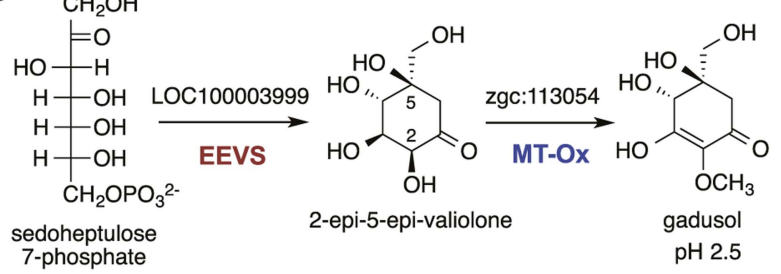

B

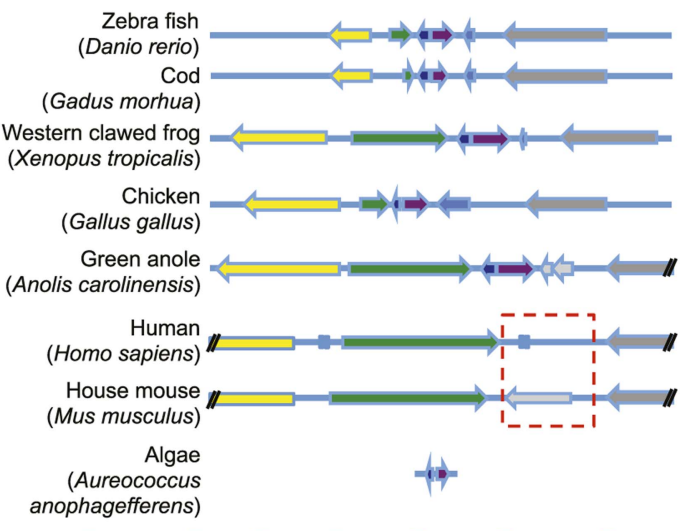

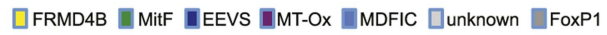
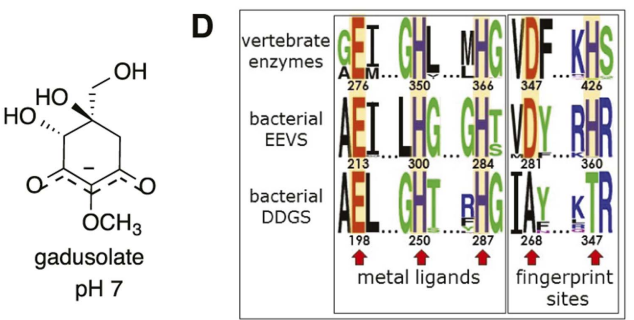

Figure 1. Bioinformatic analysis of sugar phosphate cyclases in prokaryotes and eukaryotes and biochemical characterization of gadusol biosynthetic enzymes. (A) Bayesian phylogenetic tree of SPCs. Numbers represent posterior probability. The stramenopile Aureococcus anophagefferens, denoted by the blue star, has EEVS and MT-Ox proteins strikingly similar (over 50\% identical) to those in vertebrates. The micro algae Coccomyxa subellipsoidea, denoted by the red star, also has EEVS and MT-Ox. (B) Genetic organizations of EEVS and MT-Ox genes in fish, amphibians, birds, and reptiles. Humans and other mammals lack these genes (indicated in dashed red box). For a complete list of vertebrates whose genomes are known to contain EEVS and MT-Ox genes, see Table 1. FRMD4B, FERM domain-containing protein 4B; MitF,

microphtalmia-associated transcription factor; MDFIC, MyoD-family inhibitor domain-containing protein-like; and FoxP1, Forkhead-related transcription factor 1. (C) Biochemical characterization of recombinant LOC100003999 and zgc:113054 proteins. (D) WebLogo (Crooks et al., 2004) images of residue conservation patterns at the three metal ligand positions and two active site fingerprint sites known (Kean et al., 2014) to distinguish bacterial EEVSs from DDGSs. The residue numbers given correspond to the reference proteins $D$. rerio EEVS, ValA, and A. variabilis DDGS, respectively. WebLogos were based on 126 vertebrate, 63 bacterial EEVS, and 160 bacterial DDGS sequences, respectively, that had BLASTP E-values $<10^{-120}$ in searches using the reference proteins noted above as queries. Each group was aligned using ProMals (Pei and Grishin, 2007).

DOI: 10.7554/eLife.05919.003

The following source data and figure supplements are available for figure 1:

Source data 1. Amino acid sequences of the Sugar Phosphate Cyclases (SPCs). DOI: 10.7554/eLife.05919.004

Figure supplement 1. Biosynthetic pathway to shinorine in Anabaena variabilis (Balskus and Walsh, 2010). DOI: 10.7554/eLife.05919.005

Figure supplement 2. Maximum likelihood phylogenetic tree of sugar phosphate cyclases. DOI: 10.7554/eLife.05919.006

Figure supplement 3. SDS PAGE of EEVS and MT-Ox proteins and thin-layer chromatography (TLC) analysis of their products. DOI: 10.7554/eLife.05919.007

Figure supplement 4. GC-MS analysis of LOC100003999 and ValA reaction products.

DOI: 10.7554/eLife.05919.008

Figure supplement 5. Sequences of the vertebrate clade of EEVS-related proteins have characteristic features of an EEVS. DOI: 10.7554/eLife.05919.009

Figure supplement 6. Stereoview for the modeled active site geometry of LOC100003999.

DOI: 10.7554/eLife.05919.010 
Table 1. Genetic analysis of EEVS and MT-Ox genes in some invertebrates and chordates

\section{Class}

Cnidaria

nvertebrate

chordates

Agnatha

Chondrichthyes

Osteichthyes

(Actinopterygii)
Hydra vulgaris

Sarcopterygii

Amphibia

Reptilia

Aves

\section{Table 1. Continued on next page}

Species

Acropora digitifera

Nematostella vectensis

Ciona intestinalis

Branchiostoma floridae

Petromyzon marinus

Callorhinchus milii

Astyanax mexicanus

Danio rerio

Dicentrarchus labrax

Fundulus heteroclitus

Gadus morhua

Gasterosteus aculeatus

Lepisosteus oculatus

Maylandia zebra

Neolamprologus brichardi

Oncorhynchus mykiss

Orechromis niloticus

Oryzias latipes

Poecilia formosa

Pundamilia nyererei

Salmo salar

Takifugu rubripes

Tetraodon nigroviridis

Xiphophorus maculatus

\section{Common name}

Coral*

Latimeria chalumnae

Xenopus tropicalis

Alligator mississippiensis

Anolis carolinensis

Chelonia mydas

Chrysemys picta bellii

Ophiophagus hannah

Pelodiscus sinensis

Python bivittatus

Anas platyrhynchos

Columba livia

Falco cherrug

Ficedula albicollis

Gallus gallus

Geospiza fortis

Meleagris gallopavo

Melopsittacus undulates

Pseudopodoces humilis

Taeniopygia guttata

Zonotrichia albicollis
Coral

Starlet sea anemone*

Common hydra

Vase tunicate

Florida lancelet

Lamprey†

Australian ghostshark $\dagger$

Mexican tetra

Zebra fish

European seabass

Mummichog

Atlantic cod

Three-spined stickleback

Spotted gar

Zebra mbuna

African cichlid

Rainbow trout

Nile tilapia

Japanese rice fish

Amazon molly

African cichlid

Atlantic salmon

Japanese puffer

Green spotted puffer

Southern platyfish

West African Coelacanth

Western clawed frog

American alligator

Green anole

Green sea turtle

Western painted turtle

King cobra†

Chinese softshell turtle

Burmese pythont

Mallard

Rock dove

Saker falcon

Collard flycatcher

Chicken

Medium ground-finch

North American wild turkey

Common pet parakeet

Tibetan ground-tit

Zebra finch

White-throated sparrow
FRMD4B MitF EEVS MT-Ox

MDFIC FoxP1 $\sqrt{ }$
-
$\sqrt{ }$

$\sqrt{ }$

$\ddagger$

$\sqrt{ }$

$\sqrt{ }$

$\sqrt{ }$

$-\quad-$

$-$

$\sqrt{ }-$

$\sqrt{ }-$

$-$

$-$

- $\sqrt{ }$

$\checkmark$

$\sqrt{ } \quad-$

$-$

$\sqrt{ } \neq \quad \neq$

$\sqrt{ } \neq$

$\sqrt{ } \sqrt{ }$

$\sqrt{ } \quad \sqrt{ }$

$\begin{array}{lll}V & v\end{array}$

$\sqrt{ }$

$\sqrt{ } \quad \sqrt{ } \quad \sqrt{ }$

$\checkmark$

$\checkmark$

$\sqrt{ }$

$\begin{array}{lll}\checkmark & V\end{array}$

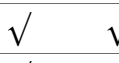

$\begin{array}{lll} & V & \\ V & & \end{array}$

$\begin{array}{lll} & v & v\end{array}$

$\sqrt{ }$

$$
\sqrt{ }
$$

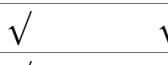

$\begin{array}{lll} & \sqrt{ } & \\ V & \sqrt{ }\end{array}$

$\begin{array}{lll}V & V\end{array}$

$\begin{array}{lll}\sqrt{ } & \checkmark\end{array}$

$\begin{array}{ll}\sqrt{ } & \sqrt{ } \\ \sqrt{ } & \sqrt{ }\end{array}$

$\begin{array}{ll}\sqrt{ } & \sqrt{ } \\ \sqrt{ } & \sqrt{ } \\ V\end{array}$

$\begin{array}{ll}\sqrt{ } & \sqrt{ } \\ \sqrt{ } & \sqrt{ }\end{array}$

V

$\sqrt{ }$

$\checkmark$

$\checkmark \quad v$

$\sqrt{ } \quad \sqrt{ }$

$\begin{array}{llll}V & \sqrt{ } & \checkmark\end{array}$

$\begin{array}{ll}\sqrt{ } & \sqrt{ } \\ \sqrt{ } & \sqrt{ }\end{array}$

$\begin{array}{llll}\sqrt{ } & \sqrt{ } & \sqrt{ } & \sqrt{ } \\ \sqrt{ } & \sqrt{ } & \sqrt{ } & \sqrt{ } \\ \sqrt{ } & \sqrt{ } & \sqrt{ } & \sqrt{ }\end{array}$

$\begin{array}{lll}\sqrt{ } & \sqrt{ } & \sqrt{ } \\ V & - & \end{array}$

$\begin{array}{lll}\sqrt{2} & \mathrm{v}\end{array}$

$\sqrt{ }-{ }_{1}-$

$\begin{array}{ccc}\sqrt{ } & \sqrt{ } & \sqrt{ } \\ \sqrt{ } & - & - \\ \sqrt{ } & \sqrt{ } & \sqrt{ }\end{array}$

$\sqrt{ } \quad \sqrt{ }$

$\begin{array}{ll}\sqrt{ } & \sqrt{ } \\ V & V\end{array}$

$\begin{array}{lll}\sqrt{ } & \sqrt{ } & \checkmark \\ \sqrt{ } & \sqrt{ } & \sqrt{ }\end{array}$

$\begin{array}{lll}\sqrt{ } & \sqrt{ } & \sqrt{ } \\ \sqrt{ } & \sqrt{ } & \sqrt{ } \\ \sqrt{ } & \sqrt{ } & \sqrt{ }\end{array}$

$\begin{array}{ll}\sqrt{ } & \sqrt{ } \\ V & \sqrt{ }\end{array}$

V

$\sqrt{ } \quad \sqrt{ }$

$\begin{array}{lll}V & V & V \\ V & \sqrt{ } & \sqrt[V]{ } \\ V & \ddagger & \end{array}$

$\begin{array}{lll}\sqrt{ } & \ddagger & \ddagger \\ \sqrt{ } & \sqrt{ } & \sqrt{ } \\ \sqrt{ } & \ddagger & \ddagger \\ V & \sqrt{ } & \sqrt{ }\end{array}$

$\sqrt{ } \quad \sqrt{ }$

$\begin{array}{ll}\sqrt{ } & \checkmark\end{array}$

$\begin{array}{lll}\sqrt{ } & \sqrt{ } & \checkmark\end{array}$

$\begin{array}{ll}\sqrt{ } & \sqrt{ } \\ \sqrt{ } & \sqrt{ }\end{array}$

$\begin{array}{lll}\sqrt{ } & \sqrt{ } & V\end{array}$

$\sqrt{ } \quad \sqrt{ }$

$\sqrt{ } \quad \sqrt{ }$

$\begin{array}{lll}\sqrt{ } & \sqrt{ } & \checkmark \\ V & \sqrt{ } & V\end{array}$

$\begin{array}{lll}\sqrt{ } & \sqrt{ } & \checkmark \\ \sqrt{ } & \sqrt{ } & V \\ V & \sqrt{ } & V\end{array}$

$\begin{array}{lll}V & V \\ V & V\end{array}$

$-$

$-$

$\sqrt{ } \quad \sqrt{ }$

$\begin{array}{lll} & & \\ V & V\end{array}$

$\begin{array}{ll}V & V \\ V & V\end{array}$

$\begin{array}{lll} & V & V \\ V & V\end{array}$

$\begin{array}{ll}\sqrt{ } & \sqrt{ } \\ \sqrt{ } & \sqrt{ } \\ \sqrt{ } & \sqrt{ }\end{array}$

$\begin{array}{lllll}\sqrt{ } & \sqrt{ } & \sqrt{ } & \sqrt{ } & \sqrt{ } \\ \sqrt{ } & \sqrt{ } & \sqrt{ } & \sqrt{ } & \sqrt{ } \\ \sqrt{ } & \sqrt{ } & \sqrt{ } & \sqrt{ } & \sqrt{ } \\ \sqrt{ } & \sqrt{ } & \sqrt{ } & \ddagger & \sqrt{ } \\ \sqrt{ } & \sqrt{ } & \sqrt{ } & \sqrt{ } & \sqrt{ }\end{array}$

V

$\checkmark \quad V$

$\begin{array}{lll}\sqrt{ } & \mathrm{V} \\ \mathrm{f} & \mathrm{V}\end{array}$

$\begin{array}{ll}\ddagger & V \\ V & V\end{array}$

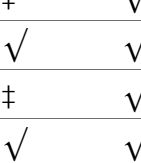

$\begin{array}{lll}V & V \\ V & V\end{array}$

- V

- $\sqrt{ }$

$\begin{array}{ll}- & \sqrt{ } \\ \ddagger & \sqrt{ }\end{array}$

$\sqrt{ } \quad \sqrt{ }$

$\sqrt{ } \quad \sqrt{ }$

$\begin{array}{ll}\sqrt{ } & \sqrt{ } \\ \sqrt{ } & \sqrt{ }\end{array}$

$\sqrt{ } \quad \sqrt{ }$

$\sqrt{ } \quad \sqrt{ }$

$\sqrt{ } \quad \sqrt{ }$

$\begin{array}{ll}\sqrt{ } & \sqrt{ } \\ \sqrt{ } & \sqrt{ }\end{array}$

$\sqrt{ } \quad \sqrt{ }$

$\sqrt{ } \quad \sqrt{ }$

$\begin{array}{ll}\sqrt{ } & V \\ V & V \\ V & V\end{array}$

$\sqrt{ } \sqrt{ } \quad \sqrt{ }$

$\begin{array}{ll}\sqrt{ } & \sqrt{ } \\ \sqrt{ } & \sqrt{ }\end{array}$

$\begin{array}{ll}\sqrt{ } & \sqrt{ } \\ \sqrt{ } & \sqrt{ }\end{array}$

$\sqrt{ } \quad \sqrt{ }$

- V

$\begin{array}{ll}- & \sqrt{ } \\ - & \sqrt{ } \\ \sqrt{ } & \sqrt{ }\end{array}$

$\begin{array}{ll}\sqrt{ } & \sqrt{ } \\ \sqrt{ } & \sqrt{ } \\ V & \sqrt{ }\end{array}$

$\begin{array}{ll}\sqrt{V} & \sqrt{ } \\ \sqrt{ } & \sqrt{ }\end{array}$


Table 1. Continued

Class

Mammalia
Species

Balaenoptera acutorostrata scammoni

\begin{tabular}{ll}
\hline Bos taurus & Cattle \\
\hline Callithrix jacchus & White-tufted-ear marmoset \\
\hline Capra hircus & Goat \\
\hline Ceratotherium simum simum & Southern white rhinoceros \\
\hline Chinchilla lanigera & Long-tailed chinchilla \\
\hline Chlorocebus sabaeus & Green monkey \\
\hline Cricetulus griseus & Chinese hamster
\end{tabular}

Eptesicus fuscus

Equus caballus

Erinaceus europaeus

Felis catus

Gorilla gorilla

Heterocephalus glaber

Homo sapiens

Lipotes vexillifer

Loxodonta africana

Macaca fascicularis

Mesocricetus auratus

Monodelphis domestica

Mus musculus

Mustela putorius furo

Myotis davidi

Myotis lucifugus

Nomascus leucogenys

Odobenus rosmarus divergens

Orcinus orca

Ornithorhynchus anatinus

Orycteropus afer

Otolemur garnettii

Ovis aries

Pan troglodytes

Papio anubis

Peromyscus maniculatus bairdii

Pteropus alecto

Rattus norvegicus

Sarcophilus harrisii

Trichechus manatus latirostris

Vicugna pacos
Common name

Minke whale

Chinese hamster

Big brown bat

Horse

Western European hedgehog

Cat

Western gorilla

Naked mole-rat

Human

Yangtze river dolphin

African savanna elephant

Crab-eating macaque

Golden hamster

Gray short-tailed opossum

House mouse

Domestic Ferret

Mouse-eared bat

Little-brown bat

Northern white-cheeked gibbon

Pacific walrus

Killer whale

Duck-billed platypus $\uparrow$

Ardvark

Small-eared galago

Sheep

Chimpanzee

Olive baboon

Prairie deer mouse

Black flying fox

Norway rat

Tasmanian devil

Florida manatee

Alpaca

FRMD4B MitF EEVS MT-Ox MDFIC FoxP1

$\begin{array}{llllllll}\sqrt{ } & \sqrt{ } & - & - & & - & \sqrt{ }\end{array}$

$\begin{array}{llllllll}\sqrt{ } & \sqrt{ } & - & - & & - & \end{array}$

$\begin{array}{llllllll}\sqrt{ } & \sqrt{ } & - & - & & - & \end{array}$

$\begin{array}{llllllll}\sqrt{ } & \sqrt{ } & - & - & & - & \sqrt{ }\end{array}$

$\begin{array}{lllllll}\sqrt{ } & \sqrt{ } & - & - & - & \sqrt{ }\end{array}$

$\begin{array}{llllllll}\sqrt{ } & \sqrt{ } & - & - & \sqrt{ } & \sqrt{ }\end{array}$

$\begin{array}{llllllll}\sqrt{ } & \sqrt{ } & - & - & \sqrt{ } & \sqrt{ }\end{array}$

$\begin{array}{lllllll}\sqrt{ } & \sqrt{ } & - & - & \sqrt{ } & \sqrt{ }\end{array}$

$\begin{array}{llllllll}\sqrt{ } & \sqrt{ } & - & - & - & \sqrt{ }\end{array}$

$\begin{array}{lllllll}\sqrt{ } & \sqrt{ } & - & - & - & \sqrt{ }\end{array}$

$\sqrt{ }$

$\sqrt{ } \quad-\quad-\quad-\quad r$

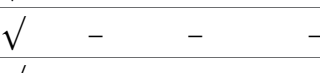

$\sqrt{ } \quad \sqrt{ }$

$\sqrt{ }-\quad-$

$-$

$\sqrt{ } \quad \sqrt{ }$

$\sqrt{ }$

$\begin{array}{lll}\sqrt{ } & - & - \\ \sqrt{ } & - & -\end{array}$

$\sqrt{ }-\quad-$

$\sqrt{ }$

$\sqrt{ }-\quad-$

$-$

$-\quad-$

$\sqrt{ }$

$\sqrt{ }-{ }^{-}-$

$\begin{array}{ll}\sqrt{ } & \sqrt{ } \\ \sqrt{ } & \sqrt{ } \\ \sqrt{ } & \sqrt{ }\end{array}$

$\begin{array}{llll}\sqrt{ } & - & - \\ \sqrt{ } & - & -\end{array}$

$\sqrt{ } \quad \sqrt{ }$

$\sqrt{ }$

$\sqrt{ }-\quad-$

$\sqrt{ } \quad-\quad-$

$\begin{array}{ll}\sqrt{ } & \sqrt{ } \\ \sqrt{ } & \sqrt{ }\end{array}$

$\begin{array}{llll}\sqrt{ } & - & - \\ \sqrt{ } & - & -\end{array}$

$\begin{array}{ll}\sqrt{ } & \sqrt{ } \\ \sqrt{ } & \sqrt{ } \\ \sqrt{ } & \sqrt{ }\end{array}$

$\begin{array}{lllll}\sqrt{ } & - & - & \sqrt{ } & \sqrt{ } \\ \sqrt{ } & - & - & - & \sqrt{ } \\ \sqrt{ } & - & - & - & \sqrt{ } \\ \sqrt{ } & - & - & - & \sqrt{ } \\ \sqrt{ } & - & - & - & \sqrt{ } \\ \sqrt{ } & - & - & - & \sqrt{ } \\ \sqrt{ } & - & - & - & \sqrt{ } \\ \sqrt{ } & - & - & - & \sqrt{ } \\ \sqrt{ } & - & - & \sqrt{ } & \sqrt{ } \\ \sqrt{ } & - & - & - & \sqrt{ } \\ \sqrt{ } & - & - & - & \sqrt{ } \\ \sqrt{ } & - & - & \sqrt{ } & \sqrt{ } \\ \sqrt{ } & - & - & - & \sqrt{ } \\ \sqrt{ } & - & - & - & \sqrt{ }\end{array}$

*Harbors genes for MAA biosynthesis.

†Incomplete genome sequence; no EEVS and MT-Ox genes identified.

$\ddagger$ The presence of EEVS or MT-Ox genes is unknown due to missing contigs or sequence information.

DOI: 10.7554/eLife.05919.011 
report bioinformatics and functional studies of zebrafish (Danio rerio) EEVS-like and MT-Ox genes and the expression of this two-enzyme pathway in yeast, and discuss the evolutionary origin of this pathway in fish, amphibians, reptiles, and birds.

\section{Results and discussion}

To investigate the function of the vertebrate EEVS-like genes, the protein encoded by the zebrafish EEVS-like gene (LOC100003999) was expressed in Escherichia coli. Incubation of the recombinant protein with SH7P gave a product, which was confirmed by thin-layer chromatography (TLC) and GCMS to be EEV (Figure 1C, Figure 1-figure supplements 3, 4), identifying the protein as an EEVS. The best-characterized bacterial EEVS is ValA from the validamycin pathway in Streptomyces hygroscopicus subsp. jinggangensis 5008 (Bai et al., 2006), and the crystal structure of ValA (Protein Data Bank [PDB] entry 4P53) (Kean et al., 2014), allowed identification of a fingerprint set of 14 active-site residues with characteristic variations that could differentiate the various SH7P cyclases. Further supporting the assignment of the LOC100003999-encoded protein as an EEVS, sequence comparisons show that all animal EEVS-like proteins are highly similar (60-72\% identity) and also match the sequence of ValA at all 14 fingerprint sites (Figure 1D, Figure 1-figure supplements 5, 6). This firmly establishes the presence of EEVS activity in animals.

The second gene, MT-Ox (zgc:113054), is predicted to encode a protein that contains two domains: the $\mathrm{N}$-terminal domain is similar to S-adenosylmethionine (SAM)-dependent methyltransferases, and the $\mathrm{C}$-terminal domain is similar to $\mathrm{NAD}^{+}$-dependent oxidoreductases. Although its function in zebrafish is unknown, the transcription of this gene in larvae is upregulated by light, leading to a prediction of its involvement in circadian clock regulation (Weger et al., 2011). In contrast, we hypothesized that this bifunctional protein is involved in modifying EEV to yield an oxidized and methylated product (Figure 1C). To test this hypothesis, recombinant MT-Ox protein encoded by zgc:113054 was incubated with EEV in the presence of SAM and NAD ${ }^{+}$. Following incubation, a product with $\lambda \max$ of $294 \mathrm{~nm}(\mathrm{pH} \mathrm{7)}$ and $270(\mathrm{pH} 2.5)$ was detected (Figure 2A-B). Further analysis of the product by (-)-ESI-MS $\left(\mathrm{m} / \mathrm{z} 203[\mathrm{M}-\mathrm{H}]^{-}\right)$and ${ }^{1} \mathrm{H}$ NMR confirmed its identity as gadusol (Figure 2-figure supplements 1, 2). We postulate that the conversion of EEV to gadusol by MT-Ox takes place via oxidation of the $\mathrm{C}-2$ or $\mathrm{C}-3 \mathrm{OH}$, followed by enolization and methylation of the resulting $\mathrm{C}-2 \mathrm{OH}$ (Figure 2-figure supplement 3 ). This new pathway to the UV-absorbing vinylogous acid functional group shared by gadusol and 4-deoxygadusol is distinct from that used in the biosynthesis of the MAAs (Balskus and Walsh, 2010; Spence et al., 2012), and the existence of multiple pathways for generating this scaffold is intriguing and may indicate that this is a privileged chemical scaffold in living organisms.

In zebrafish, both of the LOC100003999 and zgc:113054 genes are expressed during embryonic development. qRT-PCR analysis of mRNA isolated from zebrafish embryos at $12,24,48,72,96$, and $120 \mathrm{hpf}$ showed maximal expression at $72 \mathrm{hpf}$ (Figure 2C-D). To demonstrate de novo synthesis of gadusol in zebrafish, the embryos were collected at $72 \mathrm{hpf}$, lyophilized and extracted with methanol, and the extract was analyzed by HPLC and ESI-MS (Figure 2G). Our finding of gadusol in the extract unambiguously confirms the ability of zebrafish to synthesize gadusol and amends the current perception that gadusol found in fish and other vertebrates is necessarily of dietary or symbiont origin. However, as MAAs are synthesized via a different pathway and there is no evidence that fish have those biosynthetic enzymes, the accumulation of MAAs in fish would still appear to be of dietary origin (Mason et al., 1998; Zamzow, 2004).

To show that the recombinant LOC100003999 and zgc:113054 genes are sufficient for encoding gadusol synthesis, they were cloned into a yeast expression vector and transferred into a Saccharomyces cerevisiae strain, in which the transaldolase gene TAL1 had been deleted. Yeast possesses a robust pentose-phosphate pathway (Figure 2-figure supplement 4), and by removing the transaldolase enzyme, which normally metabolizes SH7P, and adding EEVS and MT-Ox, we expected to facilitate an effective shunt pathway from SH7P to gadusol. Analysis of the culture broth by HPLC, ESI-MS, and UV spectrophotometry revealed the presence of gadusol (Figure $2 \mathrm{H}$ ) and its accumulation to $\sim 20 \mathrm{mg} / \mathrm{l}$ after 5 days (Figure 2E). The results not only demonstrate the ability of the engineered yeast to produce and secrete gadusol but also present a new avenue for large-scale production of the compound for possible commercial uses, for example, sunscreen and/or antioxidant (Plack et al., 1981; Schmid et al., 2006; Cardozo et al., 2007; Arbeloa et al., 2010). 
A
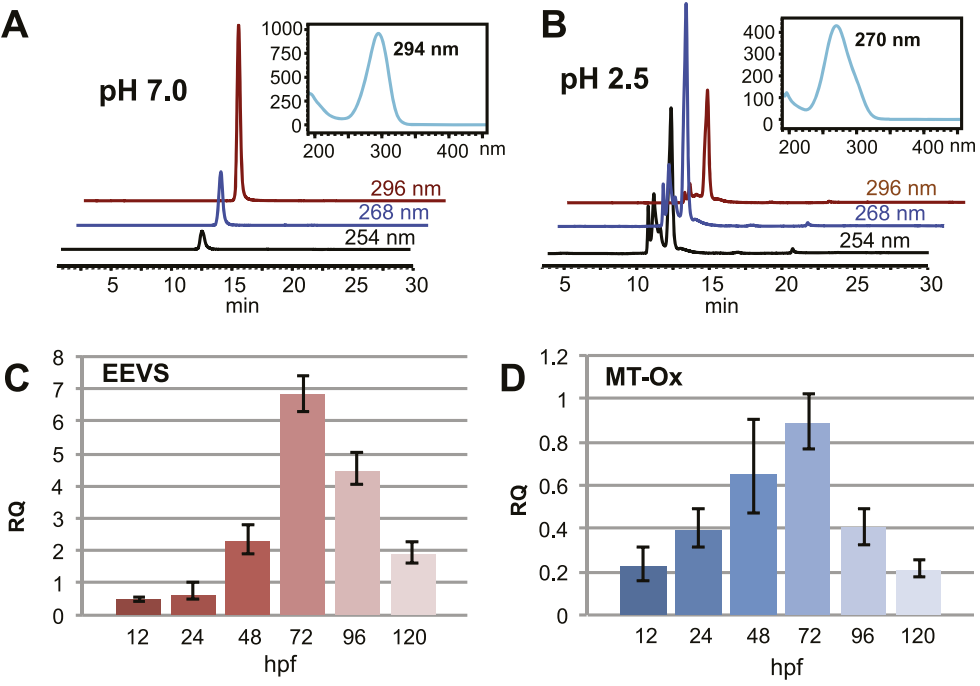

E

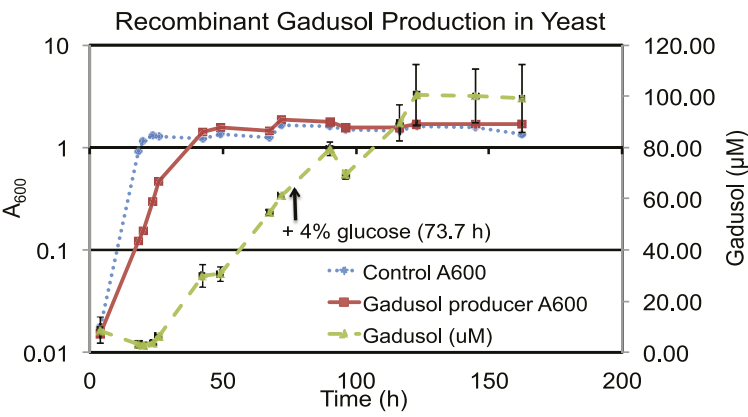

B

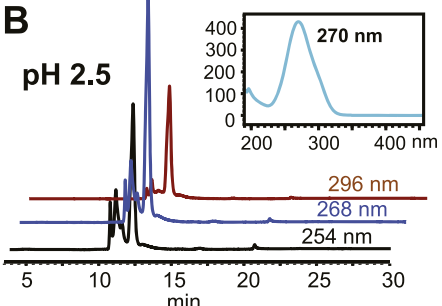

H

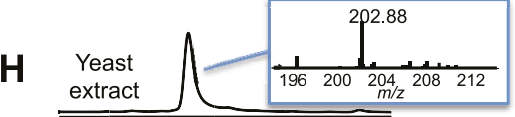

$1 0 \longdiv { 1 1 1 2 1 3 1 4 1 5 1 6 1 7 1 8 1 9 2 0 }$

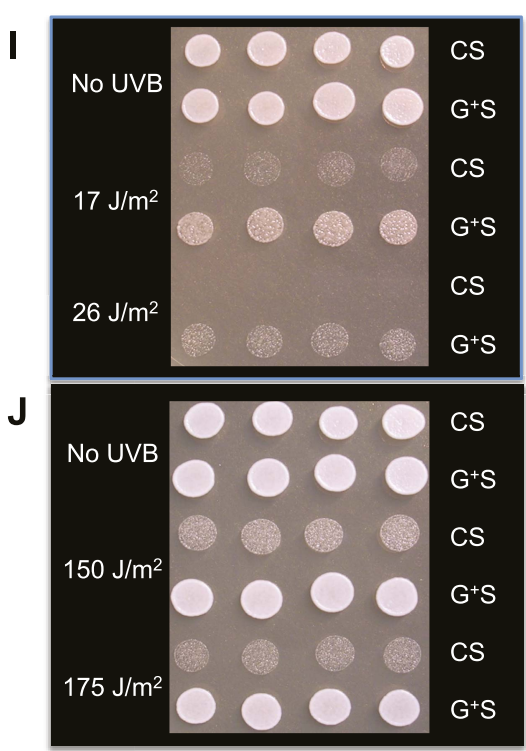

Figure 2. Production of gadusol in zebrafish and yeast and its sunscreen activity. (A-B) HPLC traces and UV absorptions of gadusol produced from Escherichia coli cell-free extract containing EEVS and purified MT-Ox protein at pH 7.0 and 2.5. (C-D) Transcription patterns of EEVS and MT-Ox genes during zebrafish embryonic development. qRT-PCR analysis of mRNA isolated from zebrafish embryos $(n=3)$ at 12, 24, 48, 72, 96, and 120 hpf. (E) Time course of gadusol production in yeast harboring the zebrafish genes. The yeast was cultured in YNB $+2 \%$ glucose supplemented with leucine and lysine at $30^{\circ} \mathrm{C}$ for 2 days, and growth was monitored as $A_{600}$ values (control, dotted blue line; gadusol producer, solid red line). Gadusol concentration in the supernatant of $20 \mathrm{ml}$ cultures $(n=3)$ was monitored as $A_{296}$ values in $50 \mathrm{mM}$ phosphate buffer, $\mathrm{pH} 7.0$ (dashed green line) corrected for nongadusol background absorbance in the control supernatant, normalized to $A_{600}$ value. Gadusol was quantified based on an extinction coefficient of $21,800 \mathrm{M}^{-1} \mathrm{~cm}^{-1}$ in $50 \mathrm{mM}$ phosphate buffer, $\mathrm{pH}$ 7. (F-H) Comparative HPLC analysis of gadusol from recombinant enzymatic reaction, zebrafish extract, and yeast extract. (I) Gadusol suppresses the UVB sensitivity of a rad14 yeast mutant; and (J) Gadusol increases the UVB tolerance of a wild-type (RAD1) strain. Cells suspended in control supernatant (CS) or gadusol ${ }^{+}$supernatant $\left(\mathrm{G}^{+} \mathrm{S}\right)$ were irradiated with UVB and subsequently spotted in $3 \mu \mathrm{l}$ aliquots $(n=4)$ onto YEPD plates, which were incubated at $30^{\circ} \mathrm{C}$ for $24 \mathrm{hr}$.

DOI: 10.7554/eLife.05919.012

The following figure supplements are available for figure 2:

Figure supplement 1. (-)-ESI-MS analysis of LOC100003999 and zgc:113054 reaction products. DOI: 10.7554/eLife.05919.013

Figure supplement 2. 'H NMR spectrum of gadusol obtained from E. coli cell free extracts containing LOC100003999 and zgc:113054 reactions. DOI: 10.7554/eLife.05919.014

Figure supplement 3. Proposed mode of formation of gadusol in vertebrates.

DOI: 10.7554/eLife.05919.015

Figure supplement 4. The Pentose Phosphate Pathway (Asamizu et al., 2012) and the shunt pathway to gadusol.

DOI: 10.7554/eLife.05919.016

To test the UV-protective activity of gadusol, a yeast rad1 $1 \Delta$ mutant, which is sensitive to UVB, was suspended at approximately $10^{7}$ cells $/ \mathrm{mL}$ in the concentrated supernatant from the gadusolproducing yeast strain or from an otherwise isogenic control strain that did not produce gadusol. The gadusol-containing supernatant suppressed the UVB-sensitivity of the rad1A mutant (Figure 2I), 
confirming the UVB-protective activity of gadusol. Analogous experiments with a wild-type strain (RAD1) at higher doses of UVB showed comparable results (Figure 2J), consistent with UVB protective activity.

As noted above, the SPCs EEVS, EVS, DDGS, aminoDHQS, and DOIS are all related to DHQS and are widespread in bacteria and fungi, but other than this report, are not known to exist in vertebrates or prevertebrates. We suggest that the vertebrate EEVS and MT-Ox genes were most plausibly acquired via horizontal gene transfer. Interestingly, searches identify the stramenopile Aureococcus anophagefferens and the microalgae Coccomyxa subellipsoidea, as the only non-vertebrate organisms in current databases that harbor a similar bifunctional MT-Ox gene, and both organisms have a predicted EEVS gene adjacent to that of MT-Ox. As algae are known to be active horizontal gene transfer agents (Ni et al., 2012), algae such as these become a plausible place both for the development of this alternate pathway for gadusol production and as a source of the genes found in vertebrates. Further supporting such a relationship, the $A$. anophagefferens EEVS protein is substantially more similar to the vertebrate EEVSs than it is to bacterial EEVSs (Figure 1A and Figure 1-figure supplement 2, denoted by the blue star).

Further bioinformatics studies also showed that the tunicates and lancelets lack the EEVS and MTOx genes, suggesting that the gene transfer occurred sometime during the evolution of primitive chordates to bony fishes (Figure 3). While the EEVS and MT-Ox genes are retained in modern rayfinned fish (with the exception of puffer fish), as well as in amphibians, reptiles, and birds, they were lost in mammals, including the egg-laying mammal platypus, indicating the lack of a direct link between gadusol and the mode of reproduction. The West African coelacanth genome (Amemiya et al., 2013) also appears to lack the EEVS and MT-Ox genes (Figure 3, Table 1). This rare ovoviviparous fish lives in caves 100-500 meters deep and feeds at night, and its lack of gadusol production ability may be directly related to its limited exposure to UV light and/or oxidative stress. Other than the well-documented presence of gadusol in fish eggs, where it can serve to protect the roe from UV damage (Arbeloa et al., 2010; Colleter et al., 2014), nothing is known of its role(s) in fish, reptiles, amphibians, and birds. Exploring its function in these organisms will increase our understanding of their physiology and ecology.

\section{Materials and methods}

\section{Molecular phylogenetic analysis}

For phylogenetic analysis, full-length amino acid sequences and vertebrate mRNA sequences were analyzed. A reciprocal BLAST hit analysis was performed with the EEVS protein (see Supplementary file 3). Sequences were aligned using MUSCLE. ProtTest was used to determine the best model of protein evolution (LG+G) (Darriba et alı, 2011), and MEGA6 was used to determine the best fit nucleic acid evolutionary model (K80+G) (Tamura et al., 2013). RAxML was used for maximum likelihood analysis, and the robustness of the trees was assessed by bootstrap analysis (1000 replicates) (Stamatakis, 2014). Bayesian analysis was performed by MrBayes (version 3.2.3), using a random starting tree, running eight chains for 4,000,000 generations, sampling every 250 trees (Ronquist et al., 2012). The first 5000 trees were discarded as the burnin, with the remaining trees used to calculate posterior probability. RAxML and MrBayes were run on the CIPRES science gateway (Miller et al., 2010). MEGA6 was used for maximum likelihood analysis of vertebrate mRNA sequences with tree robustness assessed by bootstrap (500 replicates). Sources of proteins for the analyses are listed in Supplementary file 1.

\section{Construction of LOC100003999 and zgc:113054 gene expression vectors}

The LOC100003999 gene was codon optimized for E. coli and synthesized commercially (GeneScript USA Inc., Piscataway, NJ). The product was cloned into EcoRV site of pUC57-kan vector. The plasmid was digested with Bglll and EcoRI and ligated into BamHI and EcoRI site of pRSET-B (Life Technologies, Carlsbad, CA) for the expression of $\mathrm{N}$-terminal hexa-histidine-tagged protein. The zgc: 113054 gene was also codon optimized for $E$. coli and commercially synthesized (GeneScript USA Inc.). The product was cloned into EcoRV site of pUC57-amp vector. The plasmid was digested with Bglll and EcoRI and ligated into BamHI and EcoRI site of pRSET-B (Life Technologies) for the expression of $\mathrm{N}$-terminal hexa-histidine-tagged protein. 


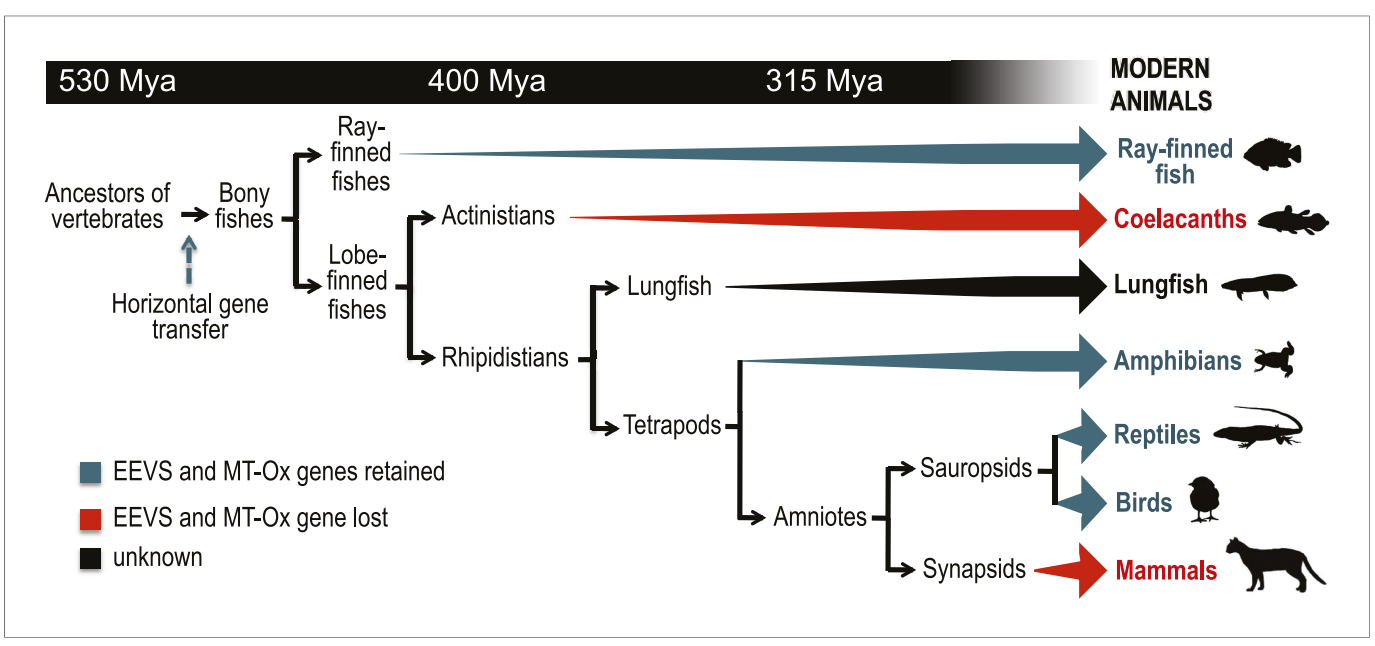

Figure 3. Model timeline for the evolution of the EEVS and MT-Ox genes in vertebrates. The genes entered an early vertebrate genome as a linked pair (vertical blue arrow) and were retained in the modern ray-finned fish, amphibians, reptiles, and birds as indicated by thick dark cyan arrows. Coelacanths and mammals lost the genes (thick red arrows). No full genome sequence is available for assessing the presence of EEVS and MT-Ox in lungfish. The phylogenetic trees of the EEVS and MT-Ox proteins or mRNA from a selected set of vertebrates can be found in Figure 3-figure supplements 1-3 and Supplementary files 1, 2.

DOI: 10.7554/eLife.05919.017

The following figure supplements are available for figure 3:

Figure supplement 1. Phylogenetic tree of the EEVS proteins from a selected set of vertebrates. DOI: 10.7554/eLife.05919.018

Figure supplement 2. Phylogenetic tree of the MT-Ox proteins from a selected set of vertebrates. DOI: 10.7554/eLife.05919.019

Figure supplement 3. Maximum likelihood tree of vertebrate EEVS mRNA sequences. DOI: 10.7554/eLife.05919.020

\section{Expression of valA, LOC100003999, and zgc:113054 genes in E. coli} pRSETB-valA, pRSETB-LOC100003999, and pRSETB-zgc:113054 plasmids were individually used to transform E. coli BL21 GOLD (DE3) pLysS. Transformants were grown overnight at $37^{\circ} \mathrm{C}$ on LB agar plate containing ampicillin $(100 \mu \mathrm{g} / \mathrm{ml})$ and chloramphenicol $(25 \mu \mathrm{g} / \mathrm{ml})$. A single colony was inoculated into LB medium $(2 \mathrm{ml})$ containing the above antibiotics and cultured at $37^{\circ} \mathrm{C}$ for $8 \mathrm{hr}$. The seed culture $(1 \mathrm{ml})$ was transferred into LB medium $(100 \mathrm{ml})$ in a $500-\mathrm{ml}$ flask and grown at $30^{\circ} \mathrm{C}$ until $\mathrm{OD}_{600}$ reached 0.6 . Then, the temperature was reduced to $18^{\circ} \mathrm{C}$. After 1 -hr adaptation, isopropyl-D-1thiogalactopyranoside (IPTG) $(0.1 \mathrm{mM})$ was added to induce the $\mathrm{N}$-terminal hexa-histidine-tagged proteins. After further growth for $16 \mathrm{hr}$, the cells were harvested by centrifugation $(5000 \mathrm{rpm}, 10 \mathrm{~min}$, $4^{\circ} \mathrm{C}$ ), washed twice with cold water, and stored at $-80^{\circ} \mathrm{C}$ until used.

\section{Purification of recombinant ValA, LOC100003999, and zgc:113054}

Cell pellets from a 400-ml culture of E. coli BL21 GOLD (DE3) pLysS containing pRSETB-valA, pRSETBLOC100003999, or pRSETB-zgc:113054 plasmids were resuspended in $20 \mathrm{ml}$ of B buffer $(40 \mathrm{mM}$ Tris- $\mathrm{HCl}, 300 \mathrm{mM} \mathrm{NaCl}, 10 \mathrm{mM}$ imidazole, $\mathrm{pH}$ 7.5). Cells were disrupted by sonication for $1 \mathrm{~min}$ (4 times, 2 min interval) at 13 watts on ice (Probe sonicator, Misonix, Farmingdale, NY). $20 \mathrm{ml}$ of lysate was divided into $2-\mathrm{ml}$ tubes and centrifuged $\left(14,500 \mathrm{rpm}, 20 \mathrm{~min}, 4^{\circ} \mathrm{C}\right)$. Soluble fractions were collected and transferred into a 50-ml tube. Ni-NTA (OIAGEN, Valencia, CA) resin (5 ml) was applied into $10-\mathrm{ml}$ vol empty column, and the Ni-NTA resin was equilibrated with $B$ buffer $(50 \mathrm{ml}, 10 \mathrm{CV}$ ). About $20 \mathrm{ml}$ of supernatant from cell lysate was applied to the column (flow rate; $0.8 \mathrm{ml} / \mathrm{min}$ ). The column was then washed with $100 \mathrm{ml}(20 \mathrm{CV})$ of W buffer $(40 \mathrm{mM}$ Tris- $\mathrm{HCl}, 300 \mathrm{mM} \mathrm{NaCl}, 20 \mathrm{mM}$ imidazole, $\mathrm{pH} 7.5$ ) at $0.8 \mathrm{ml} / \mathrm{min}$. The hexa-histidine-tagged proteins were eluted by imidazole addition using a gradient mixer containing $100 \mathrm{ml}$ of W buffer and $100 \mathrm{ml}$ of $\mathrm{E}$ buffer $(40 \mathrm{mM}$ Tris- $\mathrm{HCl}$, $300 \mathrm{mM} \mathrm{NaCl}, 300 \mathrm{mM}$ imidazole, $\mathrm{pH}$ 7.5). The fractions (150 drops or about $5 \mathrm{ml}$ ) were collected and checked by SDS-PAGE (Coomassie Blue staining). Fractions containing pure proteins were combined 
$(25 \mathrm{ml})$ and dialyzed against 2 I of D buffer $(10 \mathrm{mM}$ Tris- $\mathrm{HCl}, \mathrm{pH} 7.5) 3$ times (every $3 \mathrm{hr}$ ). Dialyzed protein solution was concentrated by ultrafiltration (MWCO $10 \mathrm{~K}$ ) to $200 \mu \mathrm{M}$ and flash frozen in liquid $\mathrm{N}_{2}$ prior to storage at $-80^{\circ} \mathrm{C}$. The yields of the purified proteins were $57 \mathrm{mg} / \mathrm{l}$ for ValA, $18 \mathrm{mg} / \mathrm{l}$ for LOC100003999, and $79 \mathrm{mg} / \mathrm{l}$ for zgc:113054.

\section{LOC100003999 assay conditions}

Each reaction mixture $(25 \mu \mathrm{l})$ contained Tris- $\mathrm{HCl}$ buffer $(20 \mathrm{mM}, \mathrm{pH} 7.5), \mathrm{NAD}^{+}(1 \mathrm{mM}), \mathrm{CoCl}_{2}$, or $\mathrm{ZnSO}_{4}(0.1 \mathrm{mM})$, SH7P $(4 \mathrm{mM})$, and purified enzymes $(0.12 \mathrm{mM})$. The mixture was incubated at $30^{\circ} \mathrm{C}$ for $2 \mathrm{hr}$. ValA (instead of LOC100003999) was used as a positive control. No enzyme (buffer only) was used as a negative control.

\section{Coupled LOC100003999 and zgc:113054 assay conditions}

Each reaction mixture $(50 \mu \mathrm{l})$ contained potassium phosphate buffer $(10 \mathrm{mM}, \mathrm{pH} 7.4), \mathrm{NAD}^{+}(2 \mathrm{mM})$, $\mathrm{CoCl}_{2}(0.2 \mathrm{mM})$, SH7P $(4 \mathrm{mM})$, and LOC100003999 cell-free extract $(20 \mu \mathrm{l})$ was incubated at $30^{\circ} \mathrm{C}$. After $6 \mathrm{hr}$, S-adenosylmethionine $(5 \mathrm{mM})$ and purified zgc:113054 $(0.1 \mathrm{mM})$ were added. The mixture was incubated at $30^{\circ} \mathrm{C}$ for another $6 \mathrm{hr}$. ValA was used (instead of LOC100003999) as a positive control. Extract of E. coli harboring pRSET B empty vector was used as a negative control.

\section{Zgc:113054 assay using $\left[6,6-{ }^{2} \mathrm{H}_{\mathbf{2}}\right]-\mathrm{EEV}$ as substrate}

A reaction mixture $(25 \mu \mathrm{l})$ containing potassium phosphate buffer $(10 \mathrm{mM}, \mathrm{pH} 7.4), \mathrm{NAD}^{+}(2 \mathrm{mM})$, $\mathrm{CoCl}_{2}(0.2 \mathrm{mM})$, S-adenosylmethionine $(5 \mathrm{mM}),\left[6,6-{ }^{2} \mathrm{H}_{2}\right]-\mathrm{EEV}(4 \mathrm{mM})$, and purified zgc: 113054 $(0.1 \mathrm{mM})$ was incubated at $30^{\circ} \mathrm{C}$ for $2 \mathrm{hr}$. Boiled zgc: 113054 was used as a negative control.

\section{TLC analysis of EEV and gadusol}

Analytical TLC was performed using silica gel plates $(60 \AA)$ with a fluorescent indicator $(254 \mathrm{~nm})$, which were visualized with a UV lamp and ceric ammonium molybdate (CAM) or $5 \% \mathrm{FeCl}_{3}$ in $\mathrm{MeOH}-\mathrm{H}_{2} \mathrm{O}$ (1:1) solutions.

\section{GC-MS analysis of EEV}

The enzymatic reaction mixtures were lyophilized, and the products were extracted with $\mathrm{MeOH}$. The $\mathrm{MeOH}$ extract was then dried and Tri-Sil HTP (Thermo Scientific, Waltham, MA) (100 $\mu$ l) was added and left to stand for $20 \mathrm{~min}$. The solvent was removed in a flow of argon gas, and the silylated products were extracted with hexanes $(100 \mu \mathrm{l})$ and injected into the GC-MS (Hewlett Packard 5890 SERIES II Gas chromatograph).

\section{Enzymatic synthesis, purification, and analysis of gadusol}

Fifty eppendorf tubes containing reaction mixtures $(100 \mu \mathrm{l}$ each), which consist of potassium phosphate buffer (10 mM, pH 7.4), SH7P (5 mM), NAD $(2 \mathrm{mM}), \mathrm{CoCl}_{2}(0.2 \mathrm{mM})$, and LOC100003999 cell-free extract $(40 \mu \mathrm{l})$, were incubated at $30^{\circ} \mathrm{C}$. After $6 \mathrm{hr}$, S-adenosylmethionine $(5.5 \mathrm{mM})$ and zgc: 113054 cell-free extracts $(30 \mu \mathrm{l})$ were added. The reaction mixtures were incubated at $30^{\circ} \mathrm{C}$ for another $6 \mathrm{hr}$. The reaction mixtures were quenched with $2 \mathrm{vol}$ of $\mathrm{MeOH}$, left to stand at $-20^{\circ} \mathrm{C}$ for $20 \mathrm{~min}$, then centrifuged at 14,500 rpm for $20 \mathrm{~min}$. The supernatants were pooled and dried under vacuum. The residual water was frozen and lyophilized. The crude sample was dissolved in water $(1 \mathrm{ml})$ and subjected to Sephadex LH-20 column chromatography using phosphate buffer $(2.5 \mathrm{mM}, \mathrm{pH} 7)$ as an eluant. Fractions containing the product as judged by MS were combined and lyophilized. Furthermore, the product was purified by HPLC (Shimadzu LC-20AD, $C_{18}$ column [YMC], $250 \times 10 \mathrm{~mm}$, $4 \mu \mathrm{m}$, flow rate $1 \mathrm{ml} / \mathrm{min})$. Solvent system: $\mathrm{MeOH}$-phosphate buffer $(5 \mathrm{mM}, \mathrm{pH} 7)$, gradient $1-100 \%$ of $\mathrm{MeOH}(0-40 \mathrm{~min})$. Peak at $12.74 \mathrm{~min}$ was collected and dried to give gadusol $(0.4 \mathrm{mg}) .{ }^{1} \mathrm{H}$ NMR (700 MHz, $\mathrm{D}_{2} \mathrm{O}$, cryo-probe): $\delta 4.10(\mathrm{~s}, 1 \mathrm{H}, \mathrm{H}-4), 3.71(\mathrm{~d}, J=12 \mathrm{~Hz}, \mathrm{H}-7 \alpha), 3.56(\mathrm{~d}, J=12 \mathrm{~Hz}, \mathrm{H}-7 \beta), 3.49$ $\left(\mathrm{s}, 3 \mathrm{H}, \mathrm{OCH}_{3}\right), 2.68(\mathrm{~d}, J=17 \mathrm{~Hz}, \mathrm{H}-6 \alpha), 2.38(\mathrm{~d}, J=17 \mathrm{~Hz}, \mathrm{H}-6 \beta)$. HR-MS (ESI-TOF) (m/z): $(\mathrm{M}+\mathrm{H})^{+}$ calculated for $\mathrm{C}_{8} \mathrm{H}_{13} \mathrm{O}_{6}$, 205.0707; found, 205.0709.

\section{Zebrafish lines and embryos}

Adult wild-type 5D zebrafish were housed at the Sinnhuber Aquatic Research Laboratory on a recirculating system maintained at $28 \pm 1{ }^{\circ} \mathrm{C}$ with a $14 \mathrm{hr}$ light per $10 \mathrm{hr}$ dark schedule. Embryos were collected from group spawns of adult zebrafish as described previously (Reimers et al., 2006), and all 
experiments were conducted with fertilized embryos according to Oregon State University Institutional Animal Care and Use Protocols. Embryos were staged accordingly as previously described (Kimmel et al., 1995) and collected by hand for all experiments. Embryos were reared in media consisting of $15 \mathrm{mM} \mathrm{NaCl}, 0.5 \mathrm{mM} \mathrm{KCl}, 1 \mathrm{mM} \mathrm{MgSO}{ }_{4}, 0.15 \mathrm{mM} \mathrm{KH}_{2} \mathrm{PO}_{4}, 0.05 \mathrm{mM} \mathrm{Na}_{2} \mathrm{HPO}_{4}$, and $0.7 \mathrm{mM} \mathrm{NaHCO}_{3}$ (Westerfield, 2000).

\section{Polymerase chain reaction}

All polymerase chain reaction (PCR) reactions were performed according to manufacturer's specifications. Cycling conditions: $96^{\circ} \mathrm{C}$ for $3 \mathrm{~min}, 95^{\circ} \mathrm{C}$ for $1 \mathrm{~min}, 65^{\circ} \mathrm{C}$ for $1 \mathrm{~min}$, and $72^{\circ} \mathrm{C}$ for 1 min per kB DNA; 35 cycles were used followed by $10 \mathrm{~min}$ at $72^{\circ} \mathrm{C}$. All PCR products were characterized on an agarose gel. If needed, the PCR product was excised from the gel and purified using the E.Z.N.A. Gel Extraction Kit (Omega Bio-tek, Norcross, GA).

\section{Quantitative PCR of zebrafish samples}

qPCR was performed on a Applied Biosystems StepOnePlus machine. The super mix PerfeCTa SYBR Green FastMix, ROX (Quanta biosciences, Gaithersburg, MD) was used. cDNA (100 ng) from time points at $6,12,24,48,72,96$, and $120 \mathrm{hpf}$ was used. Super mix (18 $\mu \mathrm{l})$ was added to bring the final volume to $20 \mu \mathrm{l}$. PCR conditions suggested by the supplier were used. For total RNA isolation, 30 embryos were homogenized in RNAzol (Molecular Research Center, Cincinnati, OH); RNA was purified according to the manufacturer's protocol. RNA was quantified by $A_{260 / 280}$ ratios measured using a SynergyMx microplate reader (Biotek, Winooski, VT) and analyzed with the Gen5 Take3 module. $1 \mu \mathrm{g}$ of RNA was used for cDNA synthesis. Superscript III First-Strand Synthesis (Life Technologies) and oligo $d(T)$ primers were used to synthesize cDNA from the total RNA.

\section{Isolation of gadusol from zebrafish}

Embryos were collected and euthanized at $72 \mathrm{hpf}$ by induced hypoxia through rapid chilling on ice for 30 min. Embryo media were removed until about $5 \mathrm{ml}$ were left and frozen at $-80^{\circ} \mathrm{C}$. Embryos were lyophilized overnight. The freeze-dried embryos were then ground with a pestle and mortar under liquid nitrogen. The powder was collected and placed in a pre-weighed glass vial. The mortar was washed with $\mathrm{MeOH}-\mathrm{H}_{2} \mathrm{O}(80: 20)$, and the solvent was added to the powder. The solvent was evaporated, and powder was weighed. The embryo powder was extracted twice with $\mathrm{MeOH}-\mathrm{H}_{2} \mathrm{O}(80: 20)$. The two extracts were combined, dried, and weighed. The extract was suspended in $\mathrm{MeOH}-\mathrm{H}_{2} \mathrm{O}(80: 20)(1 \mathrm{ml})$ and extracted twice with hexanes. The aqueous layer was recovered, dried, and weighed. The extract was suspended in $\mathrm{MeOH}$ for analysis by mass spectrometry. The extract was dissolved in phosphate buffer $\mathrm{pH} 7.0$ for identification by HPLC (Shimadzu SPD-20A system, YMC ODS-A column (4.6 id $\times 250 \mathrm{~mm}$ ), MeOH-5 $\mathrm{mM}$ phosphate buffer ( $1 \% \mathrm{MeOH}$ for $20 \mathrm{~min}$ followed by a gradient from 1 to $95 \% \mathrm{MeOH}$ in $20 \mathrm{~min}$ ), flow rate $0.3 \mathrm{ml} / \mathrm{min}, 296 \mathrm{~nm}$. The isolated gadusol was analyzed by MS (ThermoFinnigan LCQ Advantage system) and NMR (in $\mathrm{D}_{2} \mathrm{O}$; Bruker Unity 300 [300.15 MHz] spectrometer).

\section{Construction of yeast mutants}

The yeast strains used are listed in Supplementary file 4. The TRP1 gene was replaced in BY4742 tal14:: KanMX4 with a wild-type URA3 allele from S288c by standard methods (Baudin et alo, 1993). The deletion was confirmed by PCR using primer pairs TRP1DisUP/TRP1DisLO and URA3DisUP/TRP1DisLO. The BY4742 tal14::KanMX4 trp1A::URA3 strain was then co-transformed (Gietz et alo, 1992) with pXP416 and pXP420 to generate an empty vector control strain and with pXP420-EEVS and pXP416MT-Ox to generate a gadusol-producing strain. The RAD1 gene was replaced in BY4742 tal1 $\triangle:: K a n M X 4$ trp1A::URA3 with a wild-type LEU2 allele from S288c by standard methods (Reynolds et al., 1987). The deletion was confirmed by PCR using primer pairs RAD1UP/RAD1LO. The resultant BY4742 tal14:: KanMX4 trp1A::URA3 rad14::LEU2 strain was then co-transformed with pXP416 and pXP420.

\section{Media and yeast growth conditions}

Cells were pre-grown in YEPD (1\% yeast extract, $2 \%$ peptone, and $2 \%$ glucose) for transformations, and in YNB (Bacto yeast nitrogen base without amino acids) $+2 \%$ glucose supplemented with $30 \mu \mathrm{g} /$ $\mathrm{ml}$ leucine and $30 \mu \mathrm{g} / \mathrm{ml}$ lysine to select for transformants and to produce gadusol. Liquid media were sterilized by filtration using a $0.45-\mu \mathrm{m}$ filter, and agar-based media were sterilized by autoclaving. Liquid cultures were grown at $30^{\circ} \mathrm{C}$ for $48 \mathrm{hr}$ and $200 \mathrm{rpm}$; plates were incubated at $30^{\circ} \mathrm{C}$. 


\section{Yeast overexpression plasmid construction}

Plasmids are listed in Supplementary file 5. Primers used for PCR are listed in Supplementary file 6. PCR amplicons with Spel and Xhol terminal restriction sites were generated for the EEVS gene and MT-Ox gene using pRSETB-EEVS and pRSETB-MTOx as templates, respectively. The EEVS and MTOx amplicons were then digested with Spel and Xhol and ligated into Spel-digested pXP420 and Xhol-digested pXP420 and pXP416, respectively, and introduced into competent E. coli (Top 10; Life Technologies) by transformation. E. coli transformants were selected on LB plates supplemented with ampicillin $(100 \mu \mathrm{g} / \mathrm{ml})$. Transformants were then screened by digesting plasmid DNA with Spel and Xhol restriction enzymes and analyzing fragments by agarose gel electrophoresis.

\section{Identification of gadusol production in S. cerevisiae}

S. cerevisiae cell pellets from $5 \mathrm{ml}$ cultures were extracted with $\mathrm{MeOH}$, and the supernatant was extracted with $\mathrm{nBuOH}$. Extracts were concentrated and analyzed by HPLC (Shimadzu SPD-20A system, YMC ODS-A column [4.6 id $\times 250 \mathrm{~mm}$ ], MeOH-5 mM phosphate buffer $(1 \% \mathrm{MeOH}$ for 20 min followed by a gradient from 1 to $95 \% \mathrm{MeOH}$ in $20 \mathrm{~min}$ ), flow rate $0.3 \mathrm{ml} / \mathrm{min}, 296 \mathrm{~nm}$.

\section{Irradiation protocol}

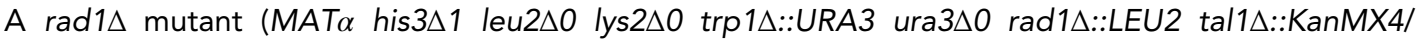
pXP416, pXP420) or wild-type RAD1 strain (S288c, MAT $\alpha$ SUC2 gal2 mal2 mel flo1 flo8-1 hap1 ho bio1 bio6) was grown at $30^{\circ} \mathrm{C}$ and $200 \mathrm{rpm}$ in YNB $+2 \%$ glucose $+30 \mu \mathrm{g} / \mathrm{ml} \mathrm{leu}+30 \mu \mathrm{g} / \mathrm{ml} \mathrm{lys}$. Cells were harvested after $24 \mathrm{hr}$ by centrifugation, washed twice in the ninefold concentrated supernatant of either the gadusol-producing strain BY4742 tal1 $\operatorname{trp} 1 \Delta / \mathrm{pXP} 416-\mathrm{MTOx}, \mathrm{pXP420-EEVS} \mathrm{or} \mathrm{of} \mathrm{the}$ control strain BY4742 tal1 $\operatorname{trp} 1 \Delta / \mathrm{pXP} 416, \mathrm{pXP} 420$, and suspended in the respective concentrated supernatants at $10^{7} \mathrm{cells} / \mathrm{ml}$. Cells $(375 \mu \mathrm{l})$ were irradiated with UVB $(302 \mathrm{~nm})$ at the indicated doses in wells of a 24-well microtiter plate shaken at $900 \mathrm{rpm} .3 \mu$ aliquots of cells were then spotted onto a YEPD plate, which was incubated $24 \mathrm{hr}$ at $30^{\circ} \mathrm{C}$ prior to being photographed. The supernatants of the gadusol producing and control strains were obtained by centrifugation following 5 day of growth in YNB $+2 \%$ glucose $+30 \mu \mathrm{g} / \mathrm{ml}$ leucine $+30 \mu \mathrm{g} / \mathrm{ml}$ lysine at $30^{\circ} \mathrm{C}$ and $200 \mathrm{rpm}$. Supernatants were freeze-dried, dissolved in a volume of distilled water $1 / 10$ of the initial culture volume, and stored at $4^{\circ} \mathrm{C}$ until use. Just prior to suspension of cells, the concentrated supernatant was adjusted to $50 \mathrm{mM}$ phosphate, $\mathrm{pH} 7.0$ resulting in a final ninefold concentrate.

\section{Acknowledgements}

This paper is dedicated to Professor Heinz G Floss on the occasion of his 80th birthday. The authors thank Canan Schumann, Oleh Taratula, Jun Ding, Allen S Yoshinaga, Zachary Landry, Edward Davis, and Seika Mahmud for technical assistance and Sinnhuber Aquatic Research Laboratory for providing zebrafish embryos. This research was supported by the Oregon State University College of Pharmacy General Research Funds and NIH grant P30 ES000210.

\section{Additional information}

Funding

\begin{tabular}{lll} 
Funder & Grant reference & Author \\
\hline National Institutes of Health (NIH) & P30 ES000210 & Robert L Tanguay \\
\hline $\begin{array}{l}\text { Oregon State University College } \\
\text { of Pharmacy }\end{array}$ & General Research Funds & Taifo Mahmud \\
\hline
\end{tabular}

The funders had no role in study design, data collection and interpretation, or the decision to submit the work for publication.

Author contributions

ARO, KHA, GH, JLD, KMK, Acquisition of data, Analysis and interpretation of data; SA, Conception and design, Acquisition of data, Analysis and interpretation of data; PAK, Analysis and interpretation of data, Drafting or revising the article; RLT, Conception and design, Analysis and interpretation of data; ATB, TM, Conception and design, Analysis and interpretation of data, Drafting or revising the article 
Author ORCIDs

Taifo Mahmud, (iD http://orcid.org/0000-0001-9639-526X

Ethics

Animal experimentation: All procedures involving animals were performed in accordance with the guidelines of the National Institutes of Health. The protocol used (4321) was approved by the Oregon State University Institutional Animal Care and Use Committee.

\section{Additional files}

Supplementary files

- Supplementary file 1. SPCs used for multiple sequence alignment and phylogenetic tree construction. DOI: 10.7554/eLife.05919.021

- Supplementary file 2. MT-Ox proteins used for multiple sequence alignment and phylogenetic tree construction.

DOI: 10.7554/eLife.05919.022

- Supplementary file 3. Reciprocal best hit analysis.

DOI: 10.7554/eLife.05919.023

- Supplementary file 4. Yeast strains used.

DOI: 10.7554/eLife.05919.024

- Supplementary file 5. Plasmids used.

DOI: 10.7554/eLife.05919.025

- Supplementary file 6. Primers used.

DOI: 10.7554/eLife.05919.026

\section{References}

Amemiya CT, Alfoldi J, Lee AP, Fan S, Philippe H, Maccallum I, Braasch I, Manousaki T, Schneider I, Rohner N, Organ C, Chalopin D, Smith JJ, Robinson M, Dorrington RA, Gerdol M, Aken B, Biscotti MA, Barucca M, Baurain D, Berlin AM, Blatch GL, Buonocore F, Burmester T, Campbell MS, Canapa A, Cannon JP, Christoffels A, De Moro G, Edkins AL, Fan L, Fausto AM, Feiner N, Forconi M, Gamieldien J, Gnerre S, Gnirke A, Goldstone JV, Haerty W, Hahn ME, Hesse U, Hoffmann S, Johnson J, Karchner SI, Kuraku S, Lara M, Levin JZ, Litman GW, Mauceli E, Miyake T, Mueller MG, Nelson DR, Nitsche A, Olmo E, Ota T, Pallavicini A, Panji S, Picone B, Ponting CP, Prohaska SJ, Przybylski D, Saha NR, Ravi V, Ribeiro FJ, Sauka-Spengler T, Scapigliati G, Searle SM, Sharpe T, Simakov O, Stadler PF, Stegeman JJ, Sumiyama K, Tabbaa D, Tafer H, Turner-Maier J, van Heusden P, White S, Williams L, Yandell M, Brinkmann H, Volff JN, Tabin CJ, Shubin N, Schartl M, Jaffe DB, Postlethwait JH, Venkatesh B, Di Palma F, Lander ES, Meyer A, Lindblad-Toh K. 2013. The African coelacanth genome provides insights into tetrapod evolution. Nature 496:311-316. doi: 10.1038/nature12027.

Arbeloa EM, Uez MJ, Bertolotti SG, Churio MS. 2010. Antioxidant activity of gadusol and occurence in fish roes from Argentine Sea. Food Chemistry 119:586-591. doi: 10.1016/j.foodchem.2009.06.061.

Asamizu S, Xie P, Brumsted CJ, Flatt PM, Mahmud T. 2012. Evolutionary divergence of sedoheptulose 7-phosphate cyclases leads to several distinct cyclic products. Journal of the American Chemical Society 134: 12219-12229. doi: 10.1021/ja3041866.

Bai L, Li L, Xu H, Minagawa K, Yu Y, Zhang Y, Zhou X, Floss HG, Mahmud T, Deng Z. 2006. Functional analysis of the validamycin biosynthetic gene cluster and engineered production of validoxylamine A. Chemical \& Biology 13: 387-397. doi: 10.1016/j.chembiol.2006.02.002.

Balskus EP, Walsh CT. 2010. The genetic and molecular basis for sunscreen biosynthesis in cyanobacteria. Science 329:1653-1656. doi: 10.1126/science.1193637.

Bandaranayake WM, Bourne DJ, Sim RG. 1997. Chemical composition during maturing and spawning of the sponge Dysidea herbacea (Porifora: Demospongiae). Comparative Biochemisty and Physiology 118B:851-859. doi: 10.1016/S0305-0491(97)00180-6.

Baudin A, Ozier-Kalogeropoulos O, Denouel A, Lacroute F, Cullin C. 1993. A simple and efficient method for direct gene deletion in Saccharomyces cerevisiae. Nucleic Acids Research 21:3329-3330. doi: 10.1093/nar/21.14.3329.

Bok MJ, Porter ML, Place AR, Cronin TW. 2014. Biological sunscreens tune polychromatic ultraviolet vision in mantis shrimp. Current Biology 24:1636-1642. doi: 10.1016/j.cub.2014.05.071.

Cardozo KH, Guaratini T, Barros MP, Falcao VR, Tonon AP, Lopes NP, Campos S, Torres MA, Souza AO, Colepicolo P, Pinto E. 2007. Metabolites from algae with economical impact. Comparative Biochemistry and Physiology Toxicology \& Pharmacology 146:60-78. doi: 10.1016/j.cbpc.2006.05.007. 
Chioccara F, Zeuli L, Novellino E. 1986. Occurence of mycosporine related compounds in sea urchin eggs. Comparative Biochemisty and Physiology 85B:459-461.

Colleter J, Penman DJ, Lallement S, Fauvel C, Hanebrekke T, Osvik RD, Eilertsen HC, D'Cotta H, Chatain B, Peruzzi S. 2014. Genetic inactivation of European sea bass (Dicentrarchus labrax L.) eggs using UV-Irradiation: observations and perspectives. PLOS ONE 9:e109572. doi: 10.1371/journal.pone.0109572.

Crooks GE, Hon G, Chandonia JM, Brenner SE. 2004. WebLogo: a sequence logo generator. Genome Research 14:1188-1190. doi: 10.1101/gr.849004.

Darriba D, Taboada GL, Doallo R, Posada D. 2011. ProtTest 3: fast selection of best-fit models of protein evolution. Bioinformatics 27:1164-1165. doi: 10.1093/bioinformatics/btr088.

Gao Q, Garcia-Pichel F. 2011. Microbial ultraviolet sunscreens. Nature Reviews Microbiology 9:791-802. doi: 10. 1038/nrmicro2649.

Garner C, Ahn R, Ding YC, Steele L, Stoven S, Green PH, Fasano A, Murray JA, Neuhausen SL. 2014. Genome-wide association study of celiac disease in North America confirms FRMD4B as new celiac locus. PLOS ONE 9: e101428. doi: 10.1371/journal.pone.0101428.

Gietz D, St Jean A, Woods RA, Schiestl RH. 1992. Improved method for high efficiency transformation of intact yeast cells. Nucleic Acids Research 20:1425. doi: 10.1093/nar/20.6.1425.

Grant PT, Middleton C, Plack PA. 1985. The isolation of four aminocyclohexenimines (mycosporines) and a structurally related derivative of cyclohexane-1:3-dione (gadusol) from the brine shrimp, Artemia. Comparative Biochemisty and Physiology 80B:755-759.

Kang Q, Shen Y, Bai L. 2012. Biosynthesis of 3,5-AHBA-derived natural products. Natural Product Reports 29 : 243-263. doi: 10.1039/c2np00019a.

Kean KM, Codding SJ, Asamizu S, Mahmud T, Karplus PA. 2014. Structure of a sedoheptulose 7-phosphate cyclase: ValA from Streptomyces hygroscopicus. Biochemistry 53:4250-4260. doi: 10.1021/bi5003508.

Kimmel CB, Ballard WW, Kimmel SR, Ullmann B, Schilling TF. 1995. Stages of embryonic development of the zebrafish. Developmental Dynamics 203:253-310. doi: 10.1002/aja.1002030302.

Levy C, Khaled M, Fisher DE. 2006. MITF: master regulator of melanocyte development and melanoma oncogene. Trends in Molecular Medicine 12:406-414. doi: 10.1016/j.molmed.2006.07.008.

Loew ER. 2014. Vision: two plus four equals six. Current Biology 24:R753-R755. doi: 10.1016/j.cub.2014.07.025.

Mahmud T. 2009. Progress in aminocyclitol biosynthesis. Current Opinion in Chemical Biology 13:161-170. doi: 10. 1016/j.cbpa.2009.02.030.

Mason DS, Schafer F, Shick JM, Dunlap WC. 1998. Ultraviolet radiation-absorbing mycosporine-like amino acids (MAAs) are acquired from their diet by medaka fish (Oryzias latipes) but not by SKH-1 hairless mice. Comparative Biochemistry and Physiology Part A, Molecular \& Integrative Physiology 120:587-598. doi: 10.1016/S1095-6433 (98)10069-7.

Miller MA, Pfeiffer W, Schwartz T. 2010. Creating the CIPRES science gateway for inference of large phylogenetic trees. Proceedings of the Gateway Computing Environments. Workshop Nov 14.

Miyamoto KT, Komatsu M, Ikeda H. 2014. Discovery of gene cluster for mycosporine-like amino acid biosynthesis from Actinomycetales microorganisms and production of a novel mycosporine-like amino acid by heterologous expression. Applied and Environmental Microbiology 80:5028-5036. doi: 10.1128/AEM.00727-14.

Ni T, Yue J, Sun G, Zou Y, Wen J, Huang J. 2012. Ancient gene transfer from algae to animals: mechanisms and evolutionary significance. BMC Evolutionary Biology 12:83. doi: 10.1186/1471-2148-12-83.

Pei J, Grishin NV. 2007. PROMALS: towards accurate multiple sequence alignments of distantly related proteins. Bioinformatics 23:802-808. doi: 10.1093/bioinformatics/btm017.

Plack PA, Fraser NW, Grant PT, Middleton C, Mitchell Al, Thomson RH. 1981. Gadusol, an enolic derivative of cyclohexane-1,3-dione present in the roes of cod and other marine fish. Isolation, properties and occurrence compared with ascorbic acid. Biochemical Journal 199:741-747.

Reimers MJ, La Du JK, Periera CB, Giovanini J, Tanguay RL. 2006. Ethanol-dependent toxicity in zebrafish is partially attenuated by antioxidants. Neurotoxicology and Teratology 28:497-508. doi: 10.1016/j.ntt.2006.05.007.

Reynolds P, Prakash L, Prakash S. 1987. Nucleotide sequence and functional analysis of the RAD1 gene of Saccharomyces cerevisiae. Molecular and Cellular Biology 7:1012-1020.

Rice GM, Raca G, Jakielski KJ, Laffin JJ, lyama-Kurtycz CM, Hartley SL, Sprague RE, Heintzelman AT, Shriberg LD. 2012. Phenotype of FOXP2 haploinsufficiency in a mother and son. American Journal of Medical Genetics Part A 158A:174-181. doi: 10.1002/ajmg.a.34354.

Ronquist F, Teslenko M, van der Mark P, Ayres DL, Darling A, Hohna S, Larget B, Liu L, Suchard MA, Huelsenbeck JP. 2012. MrBayes 3.2: efficient Bayesian phylogenetic inference and model choice across a large model space. System Biology 61:539-542. doi: 10.1093/sysbio/sys029.

Rosic NN, Dove S. 2011. Mycosporine-like amino acids from coral dinoflagellates. Applied and Environmental Microbiology 77:8478-8486. doi: 10.1128/AEM.05870-11.

Schmid D, Schürch C, Zülli F. 2006. Mycosporine-like amino acids from red algae protect against premature skinaging. Euro Cosmetics 9:1-4.

Shick JM, Dunlap WC. 2002. Mycosporine-like amino acids and related Gadusols: biosynthesis, acumulation, and UV-protective functions in aquatic organisms. Annual Review of Physiology 64:223-262. doi: 10.1146/annurev. physiol.64.081501.155802.

Shinzato C, Shoguchi E, Kawashima T, Hamada M, Hisata K, Tanaka M, Fujie M, Fujiwara M, Koyanagi R, Ikuta T, Fujiyama A, Miller DJ, Satoh N. 2011. Using the Acropora digitifera genome to understand coral responses to environmental change. Nature 476:320-323. doi: 10.1038/nature10249. 
Singh SP, Klisch M, Sinha RP, Hader DP. 2010. Genome mining of mycosporine-like amino acid (MAA) synthesizing and non-synthesizing cyanobacteria: a bioinformatics study. Genomics 95:120-128. doi: 10.1016/j.ygeno.2009. 10.002.

Spence E, Dunlap WC, Shick JM, Long PF. 2012. Redundant pathways of sunscreen biosynthesis in a cyanobacterium. Chembiochem 13:531-533. doi: 10.1002/cbic.201100737.

Stamatakis A. 2014. RAxML version 8: a tool for phylogenetic analysis and post-analysis of large phylogenies. Bioinformatics 30:1312-1313. doi: 10.1093/bioinformatics/btu033.

Starcevic A, Dunlap WC, Cullum J, Shick JM, Hranueli D, Long PF. 2010. Gene expression in the scleractinian Acropora microphthalma exposed to high solar irradiance reveals elements of photoprotection and coral bleaching. PLOS ONE 5:e13975. doi: 10.1371/journal.pone.0013975.

Tamura K, Stecher G, Peterson D, Filipski A, Kumar S. 2013. MEGA6: molecular evolutionary genetics analysis version 6.0. Molecular Biology and Evolution 30:2725-2729. doi: 10.1093/molbev/mst197.

Weger BD, Sahinbas M, Otto GW, Mracek P, Armant O, Dolle D, Lahiri K, Vallone D, Ettwiller L, Geisler R, Foulkes NS, Dickmeis T. 2011. The light responsive transcriptome of the zebrafish: function and regulation. PLOS ONE 6: e17080. doi: 10.1371/journal.pone.0017080.

Westerfield M. 2000. The zebrafish book. Eugene, OR: University of Oregon Press.

Wu X, Flatt PM, Schlorke O, Zeeck A, Dairi T, Mahmud T. 2007. A comparative analysis of the sugar phosphate cyclase superfamily involved in primary and secondary metabolism. Chembiochem 8:239-248. doi: 10.1002/cbic. 200600446.

Zamzow JP. 2004. Effects of diet, ultraviolet exposure, and gender on the ultraviolet absorbance of fish mucus and ocular structures. Marine Biology 144:1057-1064. doi: 10.1007/s00227-003-1286-2.

Zhao H, Zhou W, Yao Z, Wan Y, Cao J, Zhang L, Zhao J, Li H, Zhou R, Li B, Wei G, Zhang Z, French CA, Dekker JD, Yang Y, Fisher SE, Tucker HO, Guo X. 2015. Foxp1/2/4 regulate endochondral ossification as a suppresser complex. Developmental Biology 398:242-254. doi: 10.1016/j.ydbio.2014.12.007. 